\title{
Gaseous Elemental Mercury Exchange Fluxes over Air-Soil Interfaces in the Degraded Grasslands of Northeastern China
}

\author{
Gang Zhang ${ }^{1,2,3}{ }^{\oplus}$, Xuhang Zhou ${ }^{1}$, Xu Li ${ }^{1}$, Lei Wang ${ }^{1,4}{ }^{1}$, Xiangyun $^{2}{ }^{1}$, Zheng Luo ${ }^{1}$, Yangjie Zhang ${ }^{1}$, \\ Zhiyun Yang ${ }^{1}$, Rongfang $\mathrm{Hu}^{1}{ }^{1}$, Zhanhui Tang ${ }^{1,2,4}$, Deli Wang ${ }^{1,2,3,4}$ and Zhaojun Wang ${ }^{1,2,4, *}$ \\ 1 School of Environment, Northeast Normal University, Changchun 130117, China; \\ zhangg217@nenu.edu.cn (G.Z.); zhouxh561@nenu.edu.cn (X.Z.); lix896@nenu.edu.cn (X.L.); \\ wang1788@nenu.edu.cn (L.W.); lixy869@nenu.edu.cn (X.L.); luoz932@nenu.edu.cn (Z.L.); \\ zhangyj415@nenu.edu.cn (Y.Z.); yangzy295@nenu.edu.cn (Z.Y.); hurf556@nenu.edu.cn (R.H.); \\ tangzh789@nenu.edu.cn (Z.T.); z35976113@163.com (D.W.) \\ 2 Key Laboratory of Vegetation Ecology, Ministry of Education, Northeast Normal University, \\ Changchun 130117, China \\ 3 Institute of Grassland Science, Northeast Normal University, Changchun 130117, China \\ 4 State Environmental Protection Key Laboratory of Wetland Ecology and Vegetation Restoration, \\ Changchun 130117, China \\ * Correspondence: wangzj217@nenu.edu.cn; Tel.: +86-138-4480-1544
}

check for updates

Citation: Zhang, G.; Zhou, X.; Li, X.; Wang, L.; Li, X.; Luo, Z.; Zhang, Y.; Yang, Z.; Hu, R.; Tang, Z.; et al. Gaseous Elemental Mercury Exchange Fluxes over Air-Soil Interfaces in the Degraded Grasslands of Northeastern China. Biology 2021, 10, 917. https:// doi.org/10.3390/biology10090917

Academic Editor: Stefano Loppi

Received: 14 August 2021

Accepted: 11 September 2021

Published: 15 September 2021

Publisher's Note: MDPI stays neutral with regard to jurisdictional claims in published maps and institutional affiliations.

Copyright: (c) 2021 by the authors. Licensee MDPI, Basel, Switzerland. This article is an open access article distributed under the terms and conditions of the Creative Commons Attribution (CC BY) license (https:// creativecommons.org/licenses/by/ $4.0 /)$.
Simple Summary: This study investigated the gaseous elemental mercury exchange fluxes over Artemisia anethifolia coverage and removal and bare soil using a dynamic flux chamber attached to the Lumex ${ }^{\mathrm{R}}$ RA915+ Hg analyzer during the growing season from May to September of 2018, in which the interactive effects of plant coverage and meteorological conditions were highlighted. The results showed that the net emissions from the soil to the atmosphere, which varied diurnally, with releases occurring during the daytime hours and depositions occurring during the nighttime hours. Significant differences were observed in the fluxes between the vegetation coverage and removal during the growing months. In addition, it was determined that the mercury fluxes were positively correlated with the solar radiation and air/soil temperature levels and negatively correlated with the air humidity and soil moisture. The grassland soil served as both a source and a sink for atmospheric mercury, depending on the season and meteorological factors. The plants played an important inhibiting role in the mercury exchanges between the soil and the atmosphere. This research will potentially assist in the development of more accurate local and regional estimates of mercury emissions from degraded grassland areas and the terrestrial environment as a whole.

Abstract: Mercury (Hg) is a global pollutant that may potentially have serious impacts on human health and ecologies. The gaseous elemental mercury (GEM) exchanges between terrestrial surfaces and the atmosphere play important roles in the global Hg cycle. This study investigated GEM exchange fluxes over two land cover types (including Artemisia anethifolia coverage and removal and bare soil) using a dynamic flux chamber attached to the Lumex ${ }^{\mathrm{R}} \mathrm{RA} 915+\mathrm{Hg}$ analyzer during the growing season from May to September of 2018, in which the interactive effects of plant coverage and meteorological conditions were highlighted. The daily mean ambient levels of GEM and the total mercury concentrations of the soil (TSM) were determined to be $12.4 \pm 3.6$ to $16.4 \pm 5.6 \mathrm{ng} \cdot \mathrm{m}^{-3}$ and 32.8 to $36.2 \mathrm{ng} \cdot \mathrm{g}^{-1}$, respectively, for all the measurements from May to September. The GEM exchange fluxes $\left(\mathrm{ng} \cdot \mathrm{m}^{-2} \cdot \mathrm{h}^{-1}\right)$ during the five-month period for the three treatments included the net emissions from the soil to the atmosphere (mean 5.4 to 7.1; range of -27.0 to 47.3), which varied diurnally, with releases occurring during the daytime hours and depositions occurring during the nighttime hours. Significant differences were observed in the fluxes between the vegetation coverage and removal during the growing months $(p<0.05)$. In addition, it was determined that the $\mathrm{Hg}$ fluxes were positively correlated with the solar radiation and air/soil temperature levels and negatively correlated with the air relative humidity and soil moisture under all the conditions $(p<0.05)$. Overall, the results obtained in this study demonstrated that the grassland soil served as both a source and a sink for atmospheric $\mathrm{Hg}$, depending on the season and meteorological factors. Furthermore, the plants played an important inhibiting role in the $\mathrm{Hg}$ exchanges between the soil and the atmosphere. 
Keywords: dynamic flux chamber; mercury fluxes; soil/air interfaces; saline and alkaline land types; vegetation

\section{Introduction}

Mercury $(\mathrm{Hg})$ is considered to be a significant global pollutant due to its biochemical properties [1]. The main concerns at present regarding $\mathrm{Hg}$ are related to its mobility and persistence [2], as well as its bioaccumulation through the trophic web [3]. Gaseous mercury, which comprises over $95 \%$ of the total $\mathrm{Hg}$ in the air [4], has the ability to exist in the atmosphere for more than one year. In addition, it can travel long distances along with the atmospheric circulation, resulting in global $\mathrm{Hg}$ contamination [1,5]. Therefore, research investigations regarding the sources of $\mathrm{Hg}$ are essential in order to deepen the understanding of the biogeochemical cycle of $\mathrm{Hg}$ on a global scale [6]. Early studies have estimated that as much as $80 \%$ of the $\mathrm{Hg}$ deposited on terrestrial surfaces will be re-emitted to the atmosphere through surface emissions [7]. Those results have further indicated the importance of terrestrial environments as significant $\mathrm{Hg}$ sources in the global $\mathrm{Hg}$ cycle. The gaseous mercury exchange fluxes between atmospheric and terrestrial sources serve as important examples. However, those fluxes have been poorly characterized, and the routes by which $\mathrm{Hg}$ enters and exits the Earth's different ecosystems require further clarification [8]. It is expected that by improving the current quantification of fundamental ecosystems, accurate predictions can be made regarding the impacts that climate change will have on the global Hg cycle [9].

Many of the previous research attempts to quantify or mechanistically understand gaseous mercury fluxes were focused on forests [10,11], wetlands [12], and croplands [13]. Unfortunately, at the present time, relatively little attention has been given to grasslands, which are the largest terrestrial ecosystem type. Grasslands directly contribute to such livestock production industries as dairy, wool, and leather, which support almost a billion people worldwide [14]. Howard et al. [15] made a short-term measurement of the $\mathrm{Hg}$ fluxes from Australian alpine grassland soil. However, available data from long-term measurements and different types of grassland areas remain scarce.

The Hg fluxes between soil surfaces and the atmosphere have been extensively studied in terrestrial ecosystems during the past thirty years and have been estimated to contribute 256 to $1400 \mathrm{Mg} \cdot \mathrm{y}^{-1}$ worldwide [16,17]. Different terrestrial ecosystems have their specific functions as sink pools or net sources of mercury. For example, forests are generally regarded as active pools of $\mathrm{Hg}$. Canopy foliage uptake the majority of the $\mathrm{Hg}$ from atmospheric sources through stoma rather than root uptake [18,19]. These fixed $\mathrm{Hg}$ can be stored in live biomass (for example, stems) and then transported to the forest floor through litterfall and throughfall. The mercury will then be sequestrated in the soil [20]. The vegetation canopies, which absorb up to $99 \%$ of solar radiation, are expected to reduce $\mathrm{Hg}^{0}$ emissions by limiting the warming of the underlying soil. An earlier estimate of net $\mathrm{Hg}^{0}$ evasion from forest soils was approximately $340 \mathrm{Mg} \cdot \mathrm{y}^{-1}$ [21]. Unlike the forests, wetlands are both particularly important sinks of atmospherically deposited $\mathrm{Hg}$ and emission sources [6]. Atmospheric $\mathrm{Hg}$ deposited into wetlands via wet and dry mechanisms may easily be trapped. This is due to the fact that wet sediment tends to host more dissolved organic carbon, which can solubilize $\mathrm{Hg}$ [22]. The majority of wetlands in the background sites are relatively small pools of the environmental $\mathrm{Hg}$. Meanwhile, in Hg-enriched regions, they tend to be more significant emission sources to the atmosphere when compared with forest soils due to adequate solar radiation levels, which enhance the $\mathrm{Hg}^{2+}$ reduction to $\mathrm{Hg}^{0}$. The few studies which have been completed which involved grassland regions only focused on the $\mathrm{Hg}$ exchange fluxes between frozen layer soil and the atmosphere in alpine or high-elevation regions [15,23-25]. The results of those investigations revealed that the alpine grassland soil serves as a weak source of $\mathrm{Hg}$ released into the atmosphere but has become gradually stronger with recent climate warming trends. Meanwhile, the $\mathrm{Hg}^{0}$ fluxes 
presented obvious diurnal and seasonal variabilities, with emissions generally occurring during daytime hours and warmer seasons. In addition, depositions were observed to occur during nighttime hours and colder seasons. However, no clear agreement has been reached on the aforementioned characteristics [26]. In summary, the large uncertainties caused by different measurement methods, along with a lack of knowledge of soil-air $\mathrm{Hg}$ exchanges in grassland regions (particularly whole ecosystem soil-plus-vegetation flux data), have resulted in substantial controversy regarding the roles played by global grassland surfaces. Therefore, a definite gap in understanding currently exists in regard to the specific roles of grasslands in regional and global $\mathrm{Hg}$ biochemical cycles [6].

China's temperate steppe areas are considered to be the third-largest distribution area of grasslands in the world and one of the most widely distributed vegetation types on Earth [27]. Under the influencing effects of human activities, the land usage and coverage of the temperate steppe areas in China have undergone significant changes in recent decades. For example, large areas of grassland have been reclaimed for farmland usages, and overgrazing and expansion of residential land have resulted in serious degradation of grassland regions [28]. Grassland degradation is mainly manifested by the thinning of low grassland vegetation and the reduction in surface exposure due to litter coverage. The results of this research will potentially assist in the development of more accurate local and regional estimates of $\mathrm{Hg}$ emissions from degraded grassland areas and the terrestrial environment as a whole.

\section{Materials and Methods}

\subsection{Study Area}

The study area was located in Changling County, southwestern section of the Songnen Plains, within the eastern region of the Eurasian steppes $\left(44^{\circ} 40^{\prime}-44^{\circ} 44^{\prime} \mathrm{N}, 123^{\circ} 44^{\prime}-123^{\circ} 47^{\prime} \mathrm{E}\right)$ at an altitude range of 110 to $180 \mathrm{~m}$ (Figure 1). The site was characterized by a semi-arid continental monsoon climate, with cold, dry winters and warm, rainy summers. The annual mean temperature ranged from 4.6 to $6.4^{\circ} \mathrm{C}$. The annual precipitation ranged between 280 and $400 \mathrm{~mm}$, with $70 \%$ of the precipitation falling between the months of June and August [29]. The main soil type was characterized by high salinity and alkalization ( $\mathrm{pH}$ 8.3 to 10.0). Artemisia anethifolia, Kochia scoparia, and Artemisia scoparia were determined to be the common species at the alkaline sites. Artemisia anethifolia is the most salinity-tolerant Artemisia plant, which forms small communities on meadow grassland and dry grassland. The increase in this artemisia is often a sign of overgrazing or grassland degradation. In addition, the growing season is from May to September each year, which is the golden period for field experiments in Northeast China. So, we selected Artemisia anethifolia as our experimental species. Two types of land cover were selected within the study area: A. anethifolia and bare soil. The treatments included the original and mowing of the above-ground plants.

\subsection{Sampling Site and Experimental Design}

This study's experiments were carried out in a $25 \times 25 \mathrm{~m}^{2}$ flat and enclosed meadow steppe. Good vegetation uniformity was observed, with A. anethifolia, K. scoparia, and A. scoparia determined to be the common species at the alkaline sites. Two $0.25 \times 0.40 \mathrm{~m}^{2}$ random plots were defined during each monthly period on the basis of species composition as $A$. anethifolia and bare soil.

The experimental design included randomized blocks which were established monthly during the growing season (May to September) in 2018. This study's sampling sites were located within two blocks (A. anethifolia and bare soil), with two levels of vegetation treatments (coverage and removal) for the purpose of exploring the effects of vegetation on the Hg fluxes between the soil and the atmosphere. The soil GEM emissions were continuously measured for a 24-h duration at the center of each plot. Due to the fact that only a single instrument and a one-chamber system was available, the measurements were conducted sequentially from plot to plot during the spring (9 May to 11 May); summer 
(26 to 28 June; 21 to 23 July; and 22 to 24 August); and fall (27 to 29 September) in 2018. The measurements were obtained using a dynamic flux chamber connected to a RA-915M mercury vapor analyzer.

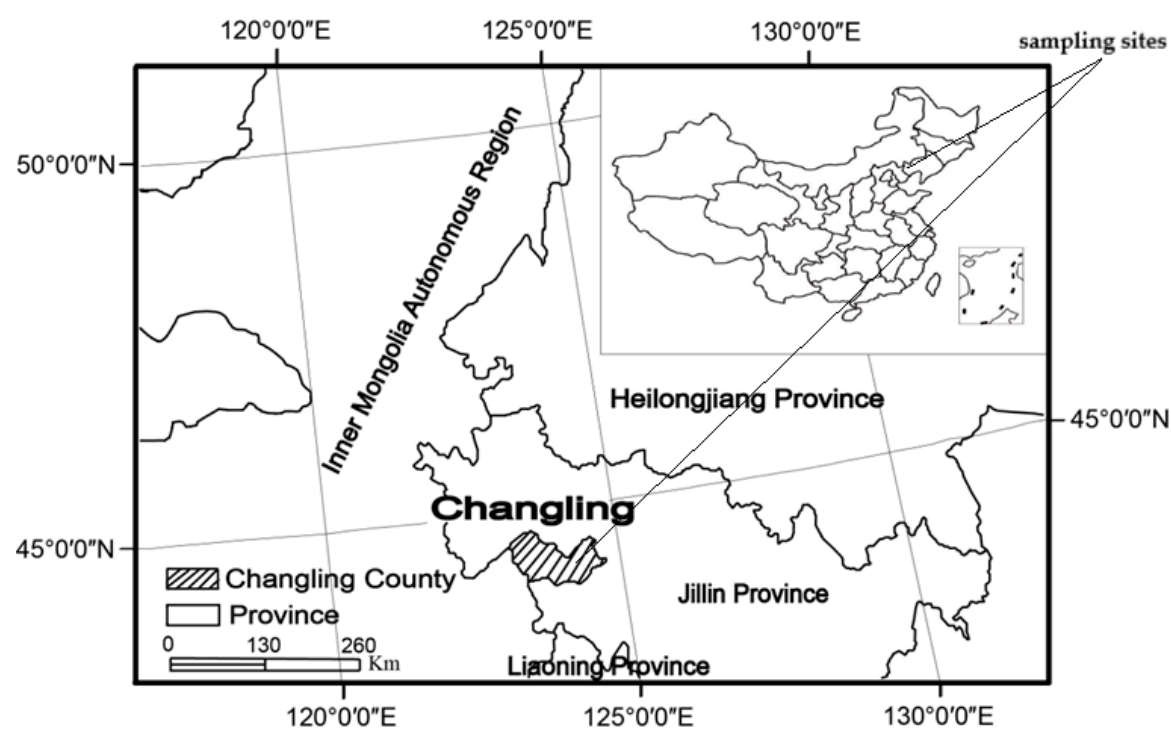

Figure 1. Map of the locations of the sampling sites.

Surface soil samples $(0-5 \mathrm{~cm})$ were collected and sealed in clean, lucifugal plastic bags for every condition. After being transported to the lab, the samples were air-dried, milled, and sieved to pass through 80 mesh-screen. The $\mathrm{Hg}$ concentrations of soil samples were analyzed by UMA (universal mercury attachment) of the Lumex RA-915+, based on the pyrolysis technology to release gaseous $\mathrm{Hg}^{0}$ from the sample to the test pool with the detection limit of $0.1 \mathrm{ng} \cdot \mathrm{g}^{-1}$.

The gaseous elemental mercury (GEM) was monitored using an automated $\mathrm{Hg}$ vapor detector produced by LUMEX RA-915+ (Russia). To be more specific, as a real-time $\mathrm{Hg}$ detector, the RA-915+ is based on the Zeeman cold vapor absorption spectrometry technique, with a time resolution of one second. It is calibrated with an internal $\mathrm{Hg}$ vapor source. Its real-time detection limit and dynamic detection extents are $2 \mathrm{ng} / \mathrm{m}^{3}$ and $5 \mathrm{ng} / \mathrm{m}^{3}$ to $2 \times 104 \mathrm{ng} / \mathrm{m}^{3}$, respectively. The average GEM concentrations were recorded every five minutes in each sampling group, and all of the measurement processes were carried out for a duration of $24 \mathrm{~h}$.

The chamber was placed over the soil surface with the vegetation coverage in order to measure the Hg fluxes, as detailed in Figure 2a,c. Then, the above-ground plants were mowed and removed from the chamber, as shown in Figure $2 \mathrm{~b}$. The mowing of the vegetation simulated grassland utilization, such as livestock grazing, particularly those occupied by pastoralists. All the measurements were performed on sunny days only, with leaf-litter present in order to mimic the original environmental conditions. In addition, for the purpose of exploring the relationships between meteorological variables and the soil $\mathrm{Hg}^{0}$ evasion, a linear regression analysis method was adopted using the hourly data from each plot across each season. In addition, using the dynamic flux chamber (DFC), the approximate $24-\mathrm{h} \mathrm{Hg}$ flux measurements under each treatment were partitioned into four periods as follows: morning (6:00 to 12:00); afternoon (12:00 to 18:00); before midnight (18:00 to 24:00); and after midnight (0:00 to 6:00), respectively. Six distinct sets of measurements were taken per day for each period. 

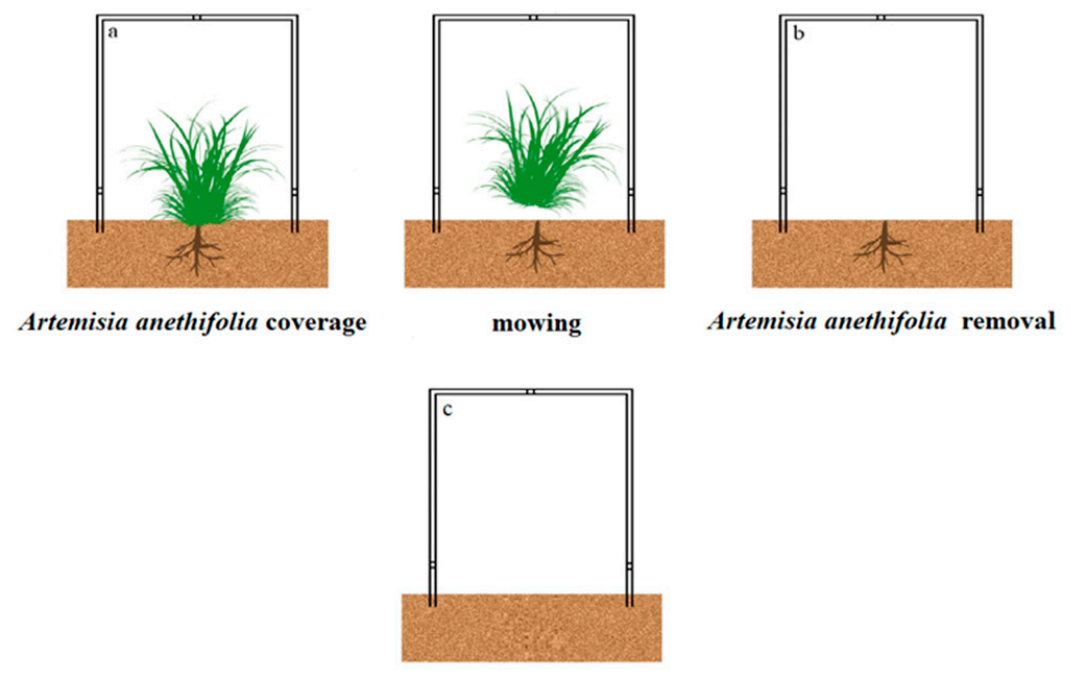

bare soil

Figure 2. Schematic diagram of the experimental design: (a,b) Artemisia anethifolia coverage and removal; and (c) Bare soil.

\subsection{Soil-Air $\mathrm{Hg}^{0}$ Flux Measurements}

In the present investigation, the $\mathrm{Hg}^{0}$ flux values were continuously sampled for $24 \mathrm{~h}$ using a cuboid dynamic flux chamber (DFC, $25 \mathrm{~cm}$ (length) $\times 40 \mathrm{~cm}$ (width) $\times 50 \mathrm{~cm}$ (height)) [30] coupled to a LUMEX ${ }^{\mathrm{R}} \mathrm{RA}-915$ + portable $\mathrm{Hg}$ vapor analyzer for each condition. Organic glass was chosen for the chamber because of its transparency and light and low chamber blanks. The chamber was linked through the outlet with the mercury analyzer by a Teflon ${ }^{\mathrm{TM}}$ tube (internal diameter of $0.635 \mathrm{~cm}$ ). The diameter of the chamber inlet was slightly larger than the outer diameter of the Teflon ${ }^{\mathrm{TM}}$ tube (outer diameter of $0.8 \mathrm{~cm}$ ) so as to ensure good airtightness. During measurement, the flux chamber was put on the surface of the area to be measured, the bottom plate of the chamber was extracted, the edge of the chamber penetrated the soil for $2 \mathrm{~cm}$, and a layer of soil around the flux covered chamber to improve the airtightness of the device. Ambient air was pumped throughout the chamber at a constant rate of $0.9 \mathrm{~m}^{3} \cdot \mathrm{h}^{-1}$. The instrument was calibrated using an internal test cell prior to each sampling period [31]. The air intake was positioned at approximately $5 \mathrm{~cm}$ above the ground on the middle side $(25 \mathrm{~cm} \times 50 \mathrm{~cm})$. The DFC inlet and outlet gases were sequentially sampled by the $\mathrm{Hg}$ vapor analyzer at 10 -min intervals (two $\times 5 \mathrm{~min}$ samples). The inlet $\mathrm{Hg}$ concentrations were analyzed as the ambient $\mathrm{Hg}^{0}$ concentrations. The $\mathrm{Hg}^{0}$ exchange fluxes of the soil surfaces and the air were calculated according to the following formula:

$$
\mathrm{F}=\left(\mathrm{Q} \cdot\left(\mathrm{C}_{\text {out }}-\mathrm{C}_{\text {in }}\right)\right) / \mathrm{A}
$$

where $\mathrm{F}$ represents the flux of the gaseous $\mathrm{Hg}$, consisting mainly of $\mathrm{Hg}^{0}\left(\mathrm{ng} \cdot \mathrm{m}^{-2} \cdot \mathrm{h}^{-1}\right)$; A refers to the bottom surface area of the chamber, which was equal to $0.1 \mathrm{~m}^{2}$; $\mathrm{Q}$ is the flushing flow rate through the chamber, equal to $0.9 \mathrm{~m}^{3} \cdot \mathrm{h}^{-1}$; and $\mathrm{C}_{\text {out }}$ and $\mathrm{C}_{\text {in }}$ represent the $\mathrm{Hg}^{0}$ concentrations of the DFC outlet and inlet gas samples, respectively $\left(\mathrm{ng} \cdot \mathrm{m}^{-3}\right)$. In the present study, in order to prevent the possibility of underestimating the $\mathrm{Hg}$ fluxes at low flushing flow rates, and to avoid the underestimation of $\mathrm{Hg}$ fluxes due to long DFC turnover times (TOT) [32,33], a constant and relatively high flow rate $\left(0.9 \mathrm{~m}^{3} \cdot \mathrm{h}^{-1}\right.$; TOT $=0.32 \mathrm{~min}$ ) was applied, which was consistent with the methods applied in previous related studies $[13,34,35]$. The mean values of two $C_{\text {out }}$ and four $C_{\text {in }}$ (before and after the $\mathrm{C}_{\text {out }}$ ) were used to calculate the $\mathrm{Hg}$ fluxes between the soil and air sequentially. One $\mathrm{Hg}$ flux datum was obtained every $10 \mathrm{~min}$. The positive and negative results calculated using Equation (1) represented the $\mathrm{Hg}$ emissions from the soil and air $\mathrm{Hg}$ dry deposition, respectively [36]. A quartz tube filled with dry soda-lime was assembled in front of the instrument gas inlet for the purpose of removing particles and acidic gases. In the field, the 
instrument was manually calibrated using an internal $\mathrm{Hg}^{0}$ permeation source before and after the sampling at each site. In addition, prior to the field campaign, the DFC was cleaned using $10 \%$ nitric acid followed by ultrapure water. The DFC blank $\left(0.5 \pm 0.3 \mathrm{ng} \mathrm{m}{ }^{-2} \cdot \mathrm{h}^{-1}\right.$; $n=20$ ) was found to be low and not corrected for in the reported flux (Equation (1)). Then, following the $\mathrm{Hg}^{0}$ flux sampling, the surface soil layers (approximately $5 \mathrm{~cm}$ ) were covered in, and the DFC footprint was collected for subsequent total soil mercury (TSM) content analysis in this study's laboratory facilities.

In addition, parallel to $\mathrm{Hg}^{0}$ flux measurements, synchronized 5-min averaged meteorological data were recorded at each sampling site using a portable weather station (ZX-SCQ4, China), including solar radiation, air temperature (inside the chamber), and relative humidity $(\mathrm{RH})$. Furthermore, we used a soil hygrometer to measure the average temperature of $0-5 \mathrm{~cm}$ soil and soil moisture (refers to mass of moisture in $100 \mathrm{~g}$ dried soil).

\subsection{Statistical Analysis Results}

This study's statistical analysis was performed using SPSS 26.0 and Origin 9.5. In addition, since the data followed normal distribution patterns, independent-samples $t$-tests were applied in order to analyze the differences in GEM and TSM. In addition, one-way analysis of variance (ANOVA) was used to analyze the variations in the $\mathrm{Hg}$ fluxes between the different examined conditions. Pearson's correlation analysis was applied to analyze the correlations between the $\mathrm{Hg}$ fluxes and measured parameters (for example, solar radiation, air temperature, and soil temperature). In the current study, the statistical analysis results were considered significant at a confidence level of 0.95 .

\section{Results}

\subsection{Gaseous Elemental Mercury (GEM) Concentrations in the Ambient Air}

The monthly mean daily GEM concentrations in the ambient air above the vegetation coverage/removal and bare soil were $14.9 \pm 6.3$ to $16.3 \pm 6.5 ; 12.4 \pm 3.6$ to $16.4 \pm 5.6$; and $12.4 \pm 3.6$ to $16.4 \pm 5.6 \mathrm{ng} \cdot \mathrm{m}^{-3}$, respectively (Table 1 ), and had ranged between 4.0 and $30.0 \mathrm{ng} \cdot \mathrm{m}^{-3}$. The peak value of $16.4 \pm 5.6 \mathrm{ng} \cdot \mathrm{m}^{-3}$ in and valley value of $12.4 \pm 3.6 \mathrm{ng} \cdot \mathrm{m}^{-3}$, respectively, occurred during the months of July and August, under the vegetation removal and bare soil conditions, respectively. Significant differences in the GEM concentrations in the ambient air between vegetation coverage and the removal were observed $(p<0.05)$. For example, when the vegetation was removed, the GEM concentrations showed substantial seasonal variations $(p<0.05)$. The GEM concentrations were generally higher than background levels for the northern hemisphere, which is considered to be approximately $1.5 \mathrm{ng} \cdot \mathrm{m}^{-3}$.

Table 1. Summary of gaseous elemental mercury concentrations $\left(n g \cdot \mathrm{m}^{-3}\right)$ for the diel in $2018(n=288)$.

\begin{tabular}{cccc}
\hline Treatments & Date & Range & Diel Mean \pm SD \\
\hline A. anethifolia cover & 9 May & $4.0 \sim 27.0$ & $16.3 \pm 6.5$ \\
A. anethifolia removal & 10 May & $5.0 \sim 26.0$ & $15.4 \pm 6.3$ \\
Bare soil & 11 May & $4.0 \sim 26.0$ & $15.4 \pm 6.3$ \\
A. anethifolia cover & 26 June & $5.0 \sim 25.0$ & $16.0 \pm 6.0$ \\
A. anethifolia removal & 27 June & $7.0 \sim 26.0$ & $16.1 \pm 6.3$ \\
Bare soil & 28 June & $7.0 \sim 25.0$ & $16.0 \pm 6.2$ \\
A. anethifolia cover & 21 July & $7.0 \sim 26.0$ & $14.9 \pm 6.3$ \\
A. anethifolia removal & 22 July & $6.0 \sim 19.0$ & $12.4 \pm 3.6$ \\
Bare soil & 23 July & $6.0 \sim 19.0$ & $12.4 \pm 3.6$ \\
A. anethifolia cover & 22 August & $8.0 \sim 26.0$ & $16.2 \pm 5.8$ \\
A. anethifolia removal & 23 August & $6.0 \sim 26.0$ & $16.4 \pm 5.6$ \\
Bare soil & 24 August & $6.0 \sim 26.0$ & $16.4 \pm 5.6$ \\
A. anethifolia cover & 27 September & $7.0 \sim 30.0$ & $16.0 \pm 6.8$ \\
A. anethifolia removal & 28 September & $6.0 \sim 27.0$ & $14.0 \pm 6.5$ \\
Bare soil & 29 September & $6.0 \sim 28.0$ & $14.1 \pm 6.6$ \\
\hline
\end{tabular}




\subsection{Total Mercury Concentrations in the Soil}

The concentration levels of total $\mathrm{Hg}$ in the soil of the study area ranged between 32.8 and $36.2 \mathrm{ng} \cdot \mathrm{g}^{-1}$ at a depth range of 0 to $5 \mathrm{~cm}$ (Table 2). The total $\mathrm{Hg}$ concentrations of the soil ranged between $32.8 \pm 1.0$ and $36.2 \pm 0.4 \mathrm{ng} \cdot \mathrm{g}^{-1}$ and peaked in the bare soil in July. On the ground where the vegetation was removed, the total $\mathrm{Hg}$ concentrations in soil were observed to have slightly declined when compared with the $\mathrm{Hg}$ concentrations with vegetation coverage. Moreover, they were not statistically different $(p>0.05)$. All of the soil $\mathrm{Hg}$ concentrations were lower than those previously reported (those observed in urban grasslands between $718 \pm 1517 \mathrm{ng} \cdot \mathrm{m}^{-2} \cdot \mathrm{h}^{-1}$ and $4115 \pm 1512 \mathrm{ng} \cdot \mathrm{m}^{-2} \cdot \mathrm{h}^{-1}$ [36] and $\mathrm{Hg}$ mining areas 33 to $3638 \mathrm{ng} \cdot \mathrm{m}^{-2} \cdot \mathrm{h}^{-1}$ ) [37]) in soil impacted by human activities and naturally enriched terrestrial landscapes in China.

Table 2. Total mercury concentrations (mean \pm SD) of the soil $\left(\mathrm{ng}^{\circ} \mathrm{g}^{-1}\right)$ for the three treatments in 2018.

\begin{tabular}{cccccc}
\hline Treatments & $\mathbf{5}$ & $\mathbf{6}$ & Month & $\mathbf{7}$ & $\mathbf{9}$ \\
\hline A. anethifolia cover & $34.8 \pm 1.5$ & $33.2 \pm 1.0$ & $35.4 \pm 1.8$ & $33.8 \pm 0.7$ & $33.2 \pm 0.7$ \\
A. anethifolia removal & $32.8 \pm 0.8$ & $32.8 \pm 0.7$ & $35.4 \pm 0.5$ & $33.8 \pm 1.0$ & $32.8 \pm 1.0$ \\
Bare soil & $35.2 \pm 1.0$ & $35.6 \pm 0.5$ & $36.2 \pm 0.4$ & $34.4 \pm 0.8$ & $33.4 \pm 0.4$ \\
\hline
\end{tabular}

\subsection{General Characteristics s of the GEM Fluxes over the Soil-Air Interfaces}

As detailed in Table 3 , the results revealed that the $\mathrm{Hg}$ fluxes ranged between -27.0 and $47.3 \mathrm{ng} \cdot \mathrm{m}^{-2} \cdot \mathrm{h}^{-1}$, with means of $5.4 \pm 14.7$ to $6.7 \pm 14.8 ; 5.9 \pm 14.2$ to $7.1 \pm 13.6$; and $5.9 \pm 11.9$ to $7.1 \pm 13.6 \mathrm{ng} \cdot \mathrm{m}^{-2} \cdot \mathrm{h}^{-1}$ for the A. anethifolia coverage, removal, and bare soil, respectively, during the 15-day measurement period (May to September). The lowest and highest $\mathrm{Hg}$ fluxes were observed for the A. anethifolia coverage in June and without vegetation in July, respectively. The GEM exchange fluxes with vegetation coverage were found to be significantly lower than those in the cases of vegetation removal $(p<0.05)$. Therefore, it is suggested that the vegetation covering the soil played an important role in the $\mathrm{Hg}$ exchanges. In total, 2558 of 4320 data points (59\%) were net emissions. The ratios of emissions and depositions were found to change seasonally, with increases observed from May to July and decreases from July to September.

Table 3. Soil-air Hg exchange fluxes $\left(\mathrm{ng} \cdot \mathrm{m}^{-2} \cdot \mathrm{h}^{-1}\right)$ for diel and the separate released and deposited periods based on measurements during the three treatments $\left(n=288, n=n_{1}+n_{2}\right)$.

\begin{tabular}{|c|c|c|c|c|c|c|c|c|c|}
\hline Treatments & Date & $\begin{array}{l}\text { Mean Hg Flux } \\
\text { (Range) }\end{array}$ & SD & Emission & SD & $\mathbf{n}_{1}$ & Deposition & SD & $\mathbf{n}_{2}$ \\
\hline A. anethifolia cover & 9 May & $6.7(-18 \sim 40.5)$ & 13.8 & 17.0 & 10.4 & 157 & -6.0 & 3.7 & 131 \\
\hline A. anethifolia removal & 10 May & $6.7(-24.8 \sim 45)$ & 15.6 & 18.1 & 11.0 & 162 & -8.6 & 4.9 & 126 \\
\hline Bare soil & 11 May & $6.2(-24.8 \sim 36)$ & 14.7 & 17.2 & 9.7 & 162 & -8.6 & 4.9 & 126 \\
\hline A. anethifolia cover & 26 June & $5.4(-27 \sim 36)$ & 14.7 & 14.5 & 10.2 & 188 & -10.3 & 7.1 & 100 \\
\hline A. anethifolia removal & 27 June & $5.9(-20.0 \sim 36.0)$ & 14.2 & 13.4 & 12.1 & 184 & -7.5 & 4.7. & 104 \\
\hline Bare soil & 28 June & $6.9(-18.0 \sim 36.0)$ & 14.3 & 14.2 & 12.8 & 184 & -6.1 & 3.3 & 104 \\
\hline A. anethifolia cover & 21 July & $6.5(-18 \sim 47.3)$ & 14.5 & 15.5 & 10.8 & 176 & -9.2 & 4.5 & 112 \\
\hline A. anethifolia removal & 22 July & $7.1(-18.0-36.0)$ & 13.6 & 17.2 & 7.2 & 170 & -8.5 & 3.6 & 118 \\
\hline Bare soil & 23 July & $7.1(-18.0 \sim 36)$ & 13.6 & 17.2 & 7.2 & 170 & -8.5 & 3.6 & 118 \\
\hline A. anethifolia cover & 22 August & $6.0(-18.0 \sim 29.0)$ & 11.0 & 13.7 & 6.0 & 177 & -7.3 & 3.0 & 111 \\
\hline A. anethifolia removal & 23 August & $6.6(-24.8 \sim 36)$ & 13.1 & 14.8 & $9 . .8$ & 176 & -7.1 & 4.3 & 112 \\
\hline Bare soil & 24 August & $6.6(-24.8 \sim 36.0)$ & 13.1 & 14.8 & 9.8 & 176 & -7.1 & 4.3 & 112 \\
\hline A. anethifolia cover & 27 September & $5.7(-18.0 \sim 36.0)$ & 12.7 & 15.9 & 9.5 & 148 & -6.3 & 3.5 & 140 \\
\hline A. anethifolia removal & 28 September & $6.5(-13.5 \sim 33.8)$ & 12.8 & 16.1 & 8.4 & 164 & -7.2 & 2.7 & 124 \\
\hline Bare soil & 29 September & $5.9(-13.5 \sim 29.3)$ & 11.9 & 14.9 & 7.2 & 164 & -7.2 & 2.7 & 124 \\
\hline
\end{tabular}

Based on this study's results, it was determined that vegetation coverage could potentially inhibit $\mathrm{Hg}$ emission from the soil. The treatment differences between the vegetation coverage, vegetation removal, and bare soil were all significant in July and August 
$(p<0.05)$, which was the most thriving period of plant growth (Figure 3). In addition, it was found that the plant community compositions had substantial effects on the $\mathrm{Hg}$ fluxes. In summary, during the vegetation growing periods, significant differences in the $\mathrm{Hg}$ fluxes were found to exist between the vegetation coverage and the vegetation removal $(p<0.05)$.
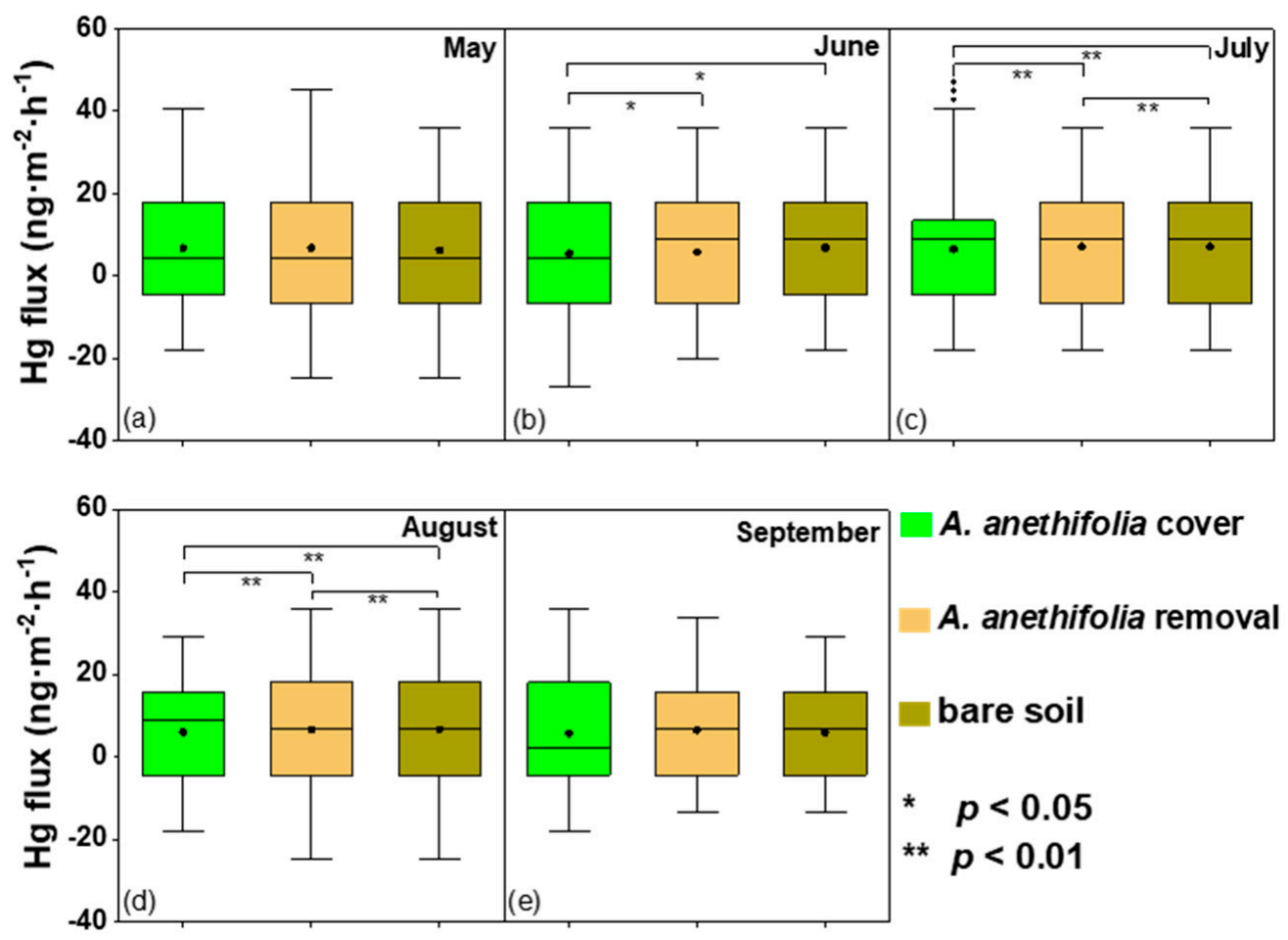

Figure 3. Box plots of the soil-air $\mathrm{Hg}$ exchange fluxes for the three examined conditions (Artemisia anethifolia coverage, Artemisia anethifolia removal, and bare soil) from May to September 2018. *: In the figure, the asterisk represents a significantly different flux compared to the other plots during the same season; sub figure (a-e) represents May to September 2018; $p<0.05$; ** $p<0.01$.

Furthermore, there were clear diurnal fluctuations in $\mathrm{Hg}$ fluxes for the three treatments, as illustrated in Figure 4. The Hg was generally released from the soil to the air during the daytime hours and deposited from the air to the soil during the nighttime hours, with peaks occurring during the middle of the day at the same time as peaks occurred in the solar radiation levels. Generally speaking, the GEM fluxes began to increase after sunrise sharply. The peaking values were observed at approximately noon (12:00 to 14:00). The valley values were observed at night before sunrise (1:00 to 3:00) and near midnight (23:00 to 24:00). The dawn (4:00 to 6:00) and late evening (18:00 to 20:00) time periods were the turning points between emissions and depositions. In nearly all cases, the peak $\mathrm{Hg}$ fluxes from the soil surfaces with vegetation coverage were lower than those with vegetation removed.

\subsection{Environmental Factors Influencing the Mercury Soil-Air Exchanges}

In the present investigation, in order to clarify the mechanism of $\mathrm{Hg}$ emissions for the three treatments, linear regression and Spearman correlation analyses between the $\mathrm{Hg}$ flux values and the meteorological parameters were derived (Figure 5, Table 4). The results revealed that higher $\mathrm{Hg}$ emission levels were observed when the solar radiation and air/soil temperature levels were high under all the examined conditions. In addition, negative correlations between the air/soil humidity and the $\mathrm{Hg}$ fluxes were observed in this study. However, it was determined that solar radiation was the most important factor influencing the $\mathrm{Hg}$ exchange fluxes under all the examined conditions $\left(\mathrm{R}^{2}=0.4337\right.$ to 0.5307). The second most important factor was air temperature $\left(R^{2}=0.2548\right.$ to 0.3561$)$. 
Those findings were in agreement with the results of previous studies [32]. Generally speaking, the increased humidity corresponded well with the decreasing solar radiation and temperature levels. However, a positive correlation between the soil moisture and the $\mathrm{Hg}$ fluxes has been noted in previous studies [38,39].
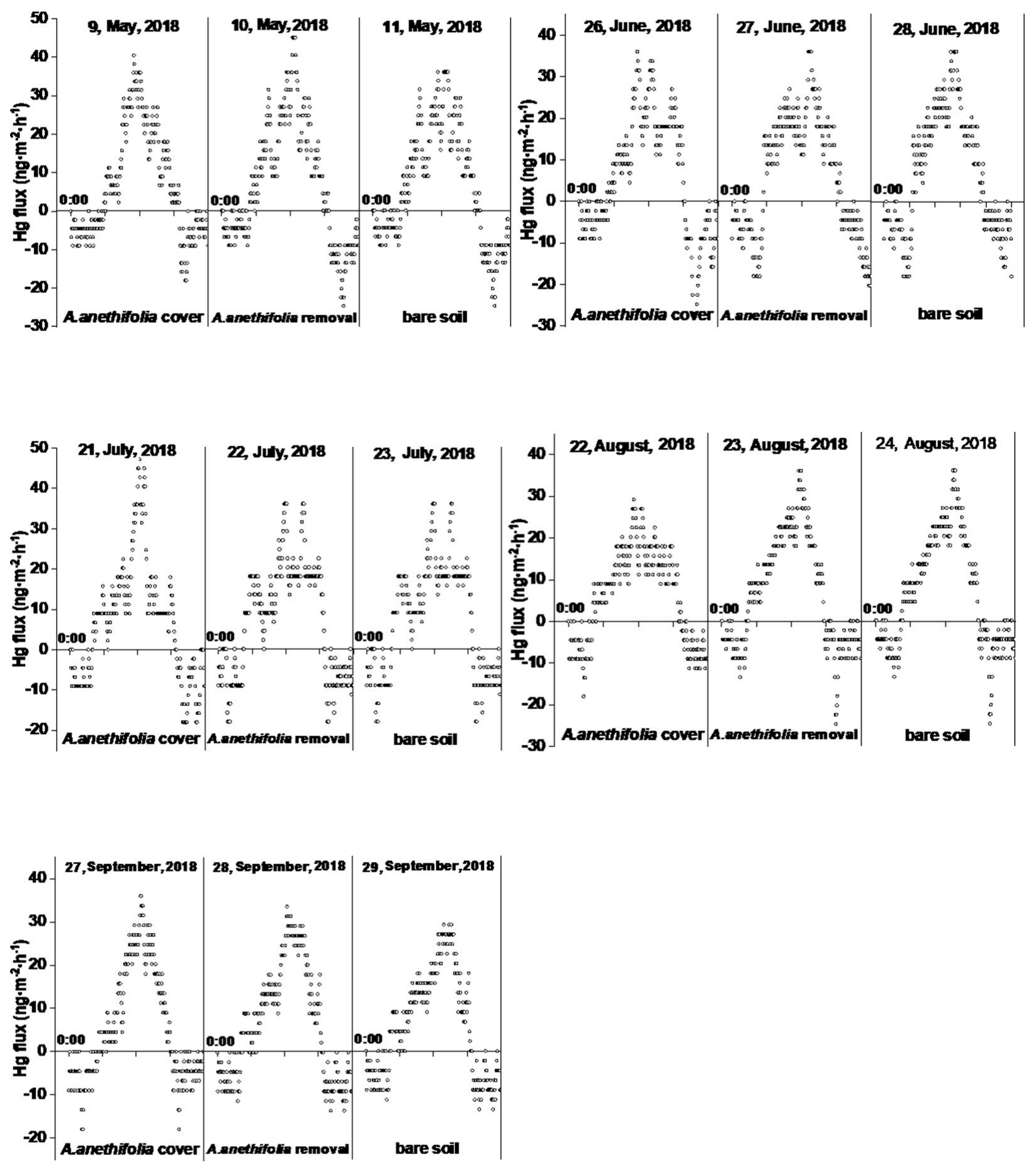

Figure 4. Diurnal variations of the $\mathrm{Hg}^{0}$ flux $\left(\mathrm{ng} \cdot \mathrm{m}^{-2} \cdot \mathrm{h}^{-1}\right)$ measurement data for the three conditions during each month. 

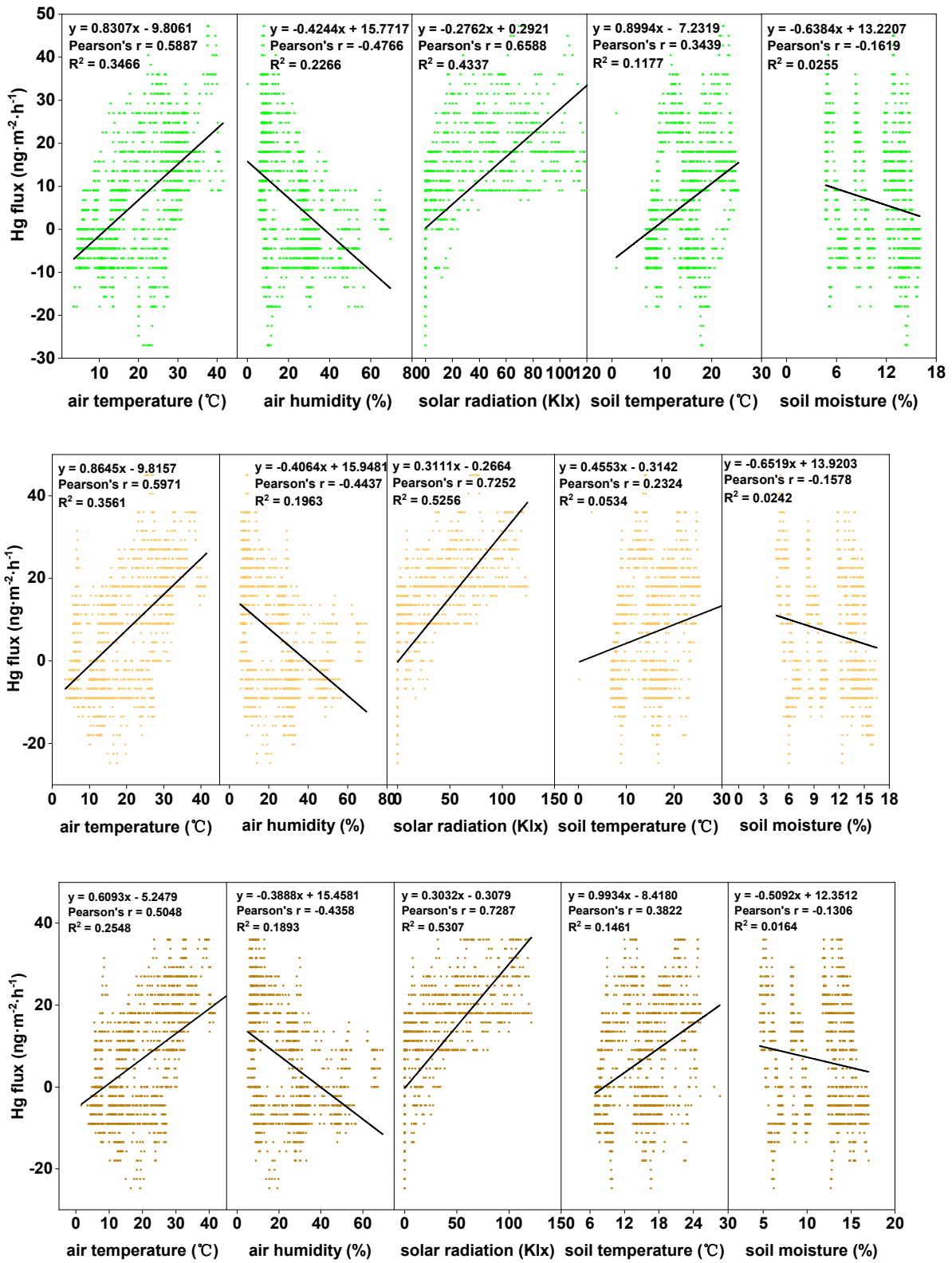

Figure 5. Correlation between the diurnal GEM fluxes with meteorological factors, such as air/soil temperatures, solar radiation, and air/soil humidity levels for the three examined conditions during the entire growing season from top to bottom: Anethifolia cover; Anethifolia removal; and bare soil.

Table 4. The Pearson's correlation between $\mathrm{Hg}$ fluxes and environmental variables under three treatments.

\begin{tabular}{cccccc}
\hline Treatments & $\begin{array}{c}\text { Air } \\
\text { Temperature }\end{array}$ & $\begin{array}{c}\text { Relative } \\
\text { Humidity }\end{array}$ & $\begin{array}{c}\text { Solar } \\
\text { Radiation }\end{array}$ & $\begin{array}{c}\text { Soil } \\
\text { Temperature }\end{array}$ & $\begin{array}{c}\text { Soil } \\
\text { Moisture }\end{array}$ \\
\hline forbs coverage & $p=0.001$ & $p=0.000$ & $p=0.000$ & $p=0.021$ & $p=0.032$ \\
forbs removal & $p=0.001$ & $p=0.001$ & $p=0.000$ & $p=0.023$ & $p=0.034$ \\
Bare soil & $p=0.001$ & $p=0.001$ & $p=0.000$ & $p=0.015$ & $p=0.036$ \\
\hline
\end{tabular}

\section{Discussion}

\subsection{General Characteristics of the GEM Fluxes}

\subsubsection{Characteristics of the GEM Fluxes of Different Terrestrial Surfaces}

This research investigation presented the soil-air $\mathrm{Hg}$ exchange flux measurements in a degraded meadow steppe located in northeastern China. Similar studies regarding GEM fluxes over other terrestrial surfaces have been conducted. (Table 5). The data used 
below is based on the DFC method. The Hg fluxes in the current study (5.4 \pm 14.7 to $6.7 \pm 14.8 ; 5.9 \pm 14.2$ to $7.1 \pm 13.6$; and $5.9 \pm 11.9$ to $7.1 \pm 13.6 \mathrm{ng} \cdot \mathrm{m}^{-2} \cdot \mathrm{h}^{-1}$ ) were observed to be much higher than the global natural emission $\left(0.7\right.$ to $\left.1.1 \mathrm{ng} \cdot \mathrm{m}^{-2} \cdot \mathrm{h}^{-1}\right)$ [40] However, the results were comparable to those observed in the studies conducted in the Changbai temperate forests $\left(4.4 \pm 28.74 \mathrm{ng} \cdot \mathrm{m}^{-2} \cdot \mathrm{h}^{-1}\right)$ [41] and croplands $(-11.8$ to $\left.7.1 \mathrm{ng} \cdot \mathrm{m}^{-2} \cdot \mathrm{h}^{-1}\right)$ in northeastern China [42]. Moreover, when compared with Hg polluted areas, the fluxes were remarkably lower than those observed in urban grasslands (between $718 \pm 1517 \mathrm{ng} \cdot \mathrm{m}^{-2} \cdot \mathrm{h}^{-1}$ and $4115 \pm 1512 \mathrm{ng} \cdot \mathrm{m}^{-2} \cdot \mathrm{h}^{-1}$ ) [36] and $\mathrm{Hg}$ mining areas (33 to $3638 \mathrm{ng} \cdot \mathrm{m}^{-2} \cdot \mathrm{h}^{-1}$ ) [37]. This study determined that the important reasons for the higher $\mathrm{Hg}$ fluxes in the aforementioned areas were the impacts of human production and livelihood pursuits, such as coal consumption and metallurgy, which contributed to elevated GEM concentrations. In contrast, the $\mathrm{Hg}$ emissions from soil in natural meadow steppe areas are the results of automatic processes which are only minimally affected by pollution or human activities.

Table 5. Characteristics of the $\mathrm{Hg}$ fluxes of different terrestrial surfaces in northeastern China.

\begin{tabular}{cc}
\hline Terrestrial Surfaces & Hg Fluxes $\mathbf{~} \mathbf{n g} \cdot \mathbf{m}^{\mathbf{- 2}} \cdot \mathbf{h}^{\mathbf{- 1}}$ ) \\
\hline Global natural emissions & $0.7-1.1$ \\
A. anethifolia cover & $5.4 \pm 14.7-6.7 \pm 14.8$ \\
A. anethifolia removal & $5.9 \pm 14.2-7.1 \pm 13.6$ \\
Bare soil & $5.9 \pm 11.9-7.1 \pm 13.6$ \\
Changbai temperate forest & $4.4 \pm 28.74$ \\
Changbai temperate cropland & $-11.8-7.1$ \\
Urban grassland & $718 \pm 1517$ and $4115 \pm 1512$ \\
Hg-mining area & $33-3638$ \\
\hline
\end{tabular}

\subsubsection{Diel Variations in the Gaseous Elemental Mercury Concentration Levels}

In the present study, there were clear diurnal fluctuations in the $\mathrm{Hg}$ fluxes under the three conditions, as illustrated in Figure 3. Generally speaking, $\mathrm{Hg}$ was released from the soil to the air during the daytime and deposited from the air to the soil during the nighttime, with peaks occurring during the middle of the day at the same time as the peaks in solar radiation. This was one of the reasons why solar radiation was considered to be the most important environmental parameter affecting the emissions of soil mercury to the atmosphere. That conclusion agreed well with the findings of previous studies $[29,43]$. The turning points of the emission and deposition processes were approximately 6:00 (morning) and 18:00 (evening). It was observed that in nearly all cases, the peaks of the $\mathrm{Hg}$ fluxes from the soil surfaces with vegetation coverage were lower than those with vegetation removed.

\subsubsection{Seasonal Variations in the Gaseous Elemental Mercury Concentration Levels}

The gaseous elemental mercury (GEM) concentrations in the ambient air presented seasonal variations during the observation periods (Figure 6). These variations were apparent, with the mean GEM concentrations decreasing with the order of August $>$ June $>$ May $>$ September $>$ July. The differences in the GEM during all the months were found to be statistically significant $(p<0.05)$, with the exceptions of June and August. The GEM concentrations in July were the lowest, while the Hg exchange fluxes were the highest. This may have been due to the influencing effects of the growing plants absorbing the gaseous $\mathrm{Hg}$ through their stoma [44]. Plants are known to accumulate $\mathrm{Hg}$ in their above-ground biomasses over the growing season [45]. In the present investigation, it was clear that the GEM concentrations were significantly elevated when compared with the background atmospheric $\mathrm{Hg}$ concentrations in China $\left(1.7 \mathrm{ng} \cdot \mathrm{m}^{-3}\right.$ in summer and $0.6 \mathrm{ng} \cdot \mathrm{m}^{-3}$ in winter) [30]. 


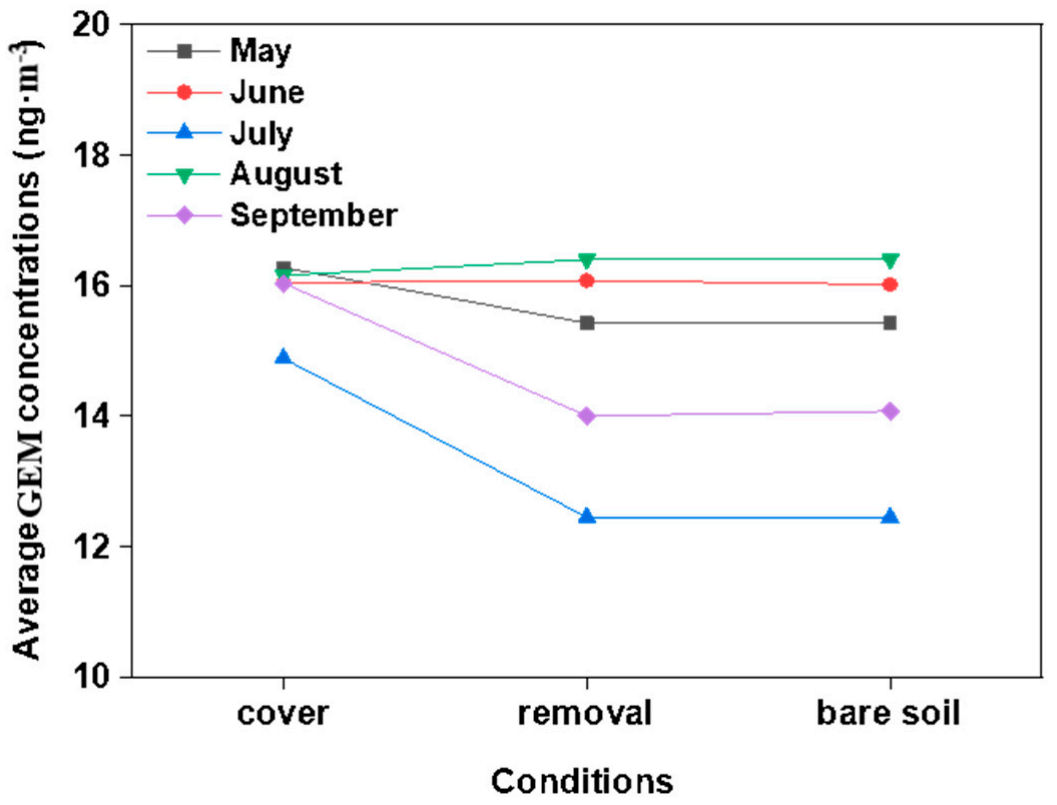

Figure 6. Twenty-four-hour average GEM concentrations under the three examined conditions during the monitored seasons.

\subsection{Impacts of Vegetation Coverage on Hg Fluxes}

In the present study, it was observed that the GEM fluxes with vegetation coverage were significantly lower than those under the conditions of removed vegetation. These findings indicated that plants may potentially inhibit $\mathrm{Hg}$ emissions from soil layers (Figure 2). Vegetation is known to have considerable impacts on air/soil Hg fluxes through the following two pathways: 1 . Altering environmental variables at the soil-air interfaces (for example, reducing solar radiation and temperature levels and changing soil properties) [46]; 2. Direct absorption of $\mathrm{Hg}$ by foliage [32]. However, when the plants were removed, the environmental variables had not displayed significant differences between vegetation coverage and vegetation removal in this study (independent-sample $t$-test; $p>0.05$ ). The increased $\mathrm{Hg}$ deposition events observed in this study's experiments were interesting phenomena that suggested that plants in the natural meadow steppe may have inhibited the $\mathrm{Hg}$ emissions from the soil mainly through absorbing atmospheric $\mathrm{Hg}$. The net ecosystem flux is the balance between soil emissions and vegetation uptake, which provides an overall estimate of whether a region is a net source or a net sink of $\mathrm{Hg}$ to the atmosphere. According to the results obtained in this study, the examined meadow steppe region was a terrestrial source of the regional $\mathrm{Hg}$ budget. With regard to the influencing effects of the grass coverage, it was observed that the contribution was lower than that without vegetation. Those results corresponded with a review of recent $\mathrm{Hg}$ flux data obtained in the northwestern American states [46]. Therefore, when accounting for the uptake of gaseous $\mathrm{Hg}$ by vegetation, the results had shifted to $62 \%$ of the terrestrial surfaces having net emissions [38].

The effects of vegetation on $\mathrm{Hg}$ fluxes have also been observed in the forest canopy studies conducted by Mazur et al. [47]. However, the influencing mechanisms in forested areas are not entirely the same as those in meadow steppe areas. The harvesting processes in forested lands tend to lead to wetter soil, with substantially more solar radiation reaching the forest floor. Studies have identified significant differences in $\mathrm{Hg}$ fluxes based on the different types of forest harvesting (clear-cut + biomass, clear-cutting, and controlled). Since biomass harvesting removes a larger quantity of vegetation when compared with traditional clear-cutting, the soil surface layers become exposed to proportionately more solar radiation. In addition, canopy shading through the growing seasons effectively limits the magnitude of $\mathrm{Hg}$ emissions from lower levels when compared with those observed 
under canopies with minimal shading, regardless of the higher air and soil temperatures experienced during those periods $[39,48]$.

\subsection{Impacts of the Meteorological Conditions and the Air/Soil Hg Content Levels}

The measurements of GEM fluxes under different coverage and meteorological conditions allowed the relationships between fluxes and meteorological conditions to be investigated. Figure 5 details the correlation coefficients for the GEM fluxes against the meteorological parameters under specific conditions. It can be seen in the figure that there were strong correlations between the fluxes and five meteorological parameters under the different coverage conditions. In summary, positive correlations were observed between the fluxes and the solar radiation and between the fluxes and the air/soil temperatures. However, negative correlations were observed between the fluxes and the relative humidity levels and between the fluxes and the soil moisture values.

\subsubsection{Solar Radiation Levels}

This study's comparison results of the correlation coefficients of the five meteorological parameters revealed that the highest positive correlation coefficients were between the fluxes and the solar radiation. Therefore, solar radiation was considered to be the most important factor affecting the GEM fluxes. Solar radiation is widely recognized as one of the most important environmental parameters affecting $\mathrm{Hg}$ emissions from the soil to the atmosphere. Solar radiation promotes the photo-reduction of $\mathrm{Hg}^{2+}$ to $\mathrm{Hg}^{0}$ [49]. During the month of July in this study, when the solar radiation was at the maximum level during the entire growing season, the $\mathrm{Hg}^{2+}$ photo-reduction had proceeded at the highest rate. This was similar to the results of a study conducted in Australian alpine grasslands by Howard et al. [26]. In addition, it has been determined that intense solar radiation levels will lead to higher air and soil temperatures, which tend to accelerate the biotic or abiotic transformation of $\mathrm{Hg}^{0}$ and enhance the mercury vapor pressure to facilitate the volatilization of mercury [50].

In the current investigation, higher correlation coefficients were obtained between the flux and solar radiation values under the $A$. anethifolia removal condition when compared with the $A$. anethifolia cover condition. These findings suggest that meteorological conditions have weaker effects on fluxes under soil-covered conditions. Furthermore, some studies have shown that the thermal energy absorbed by plants from solar radiation can increase the mercury vapor pressure and transport mercury from plants into the atmosphere by convection [47]. However, that type of phenomenon was not obvious in the current study. Therefore, it was concluded that the correlation between the solar radiation and mercury flux had increased with the decrease in vegetation coverage.

\subsubsection{Air and Soil Temperature Values}

Significant positive relationships $(p<0.01)$ between $\mathrm{Hg}$ fluxes and the air/soil temperature values were observed under all the examined conditions in this study, which was similar to the results obtained by Tao et al. [32], Choi and Holsen [51], and Lindberg [52]. The coefficients between the fluxes and the air temperature values were second only to that of the solar radiation. During the measurement processes, it was determined that the $\mathrm{Hg}^{2+}$ photo-reduction was driven by solar radiation rather than by air temperature. Therefore, solar radiation was concluded to be the main factor affecting the fluxes. The increases in solar radiation not only accelerated the photo-reduction but also increased the air temperature levels, thereby promoting $\mathrm{Hg}$ emissions [47]. The influences of air temperature on the $\mathrm{Hg}$ emissions mainly involved increasing the vapor pressure and activation energy of the chemical reactions. That mechanism is typically described using the Arrhenius Equation [47].

It has been proposed that there are at least two sources of $\mathrm{Hg}^{0}$ emitted from soil: a natural "pool" of $\mathrm{Hg}^{0}$, which is primarily absorbed on the surface, and $\mathrm{Hg}^{2+}$, which can be photochemically reduced to $\mathrm{Hg}^{0}$ by sunlight [23]. Gustin suggested that elevated soil 
temperature levels can accelerate $\mathrm{Hg}$ desorption from soil and its movement up through soil columns [53]. Therefore, under dark conditions, the primary factors leading to emissions of $\mathrm{Hg}$ from soil are generally considered to be related to the enthalpy of volatilization. However, under light conditions, the emissions will be related to both the enthalpy of volatilization and the photo-reduction process. In summary, solar radiation drives $\mathrm{Hg}$ emissions during daylight hours while soil temperature levels become the most important driving factor during nighttime hours.

\subsubsection{Air Humidity and Soil Moisture Values}

In the present investigation, the GEM fluxes and air relative humidity/soil moisture values were found to be negatively correlated under the three examined conditions. However, based on the currently obtained results, no clear conclusion was reached regarding the effects of relative humidity on $\mathrm{Hg}$ fluxes. For example, some studies have found negative correlations between $\mathrm{Hg}$ fluxes and relative humidity levels [43,51]. Meanwhile, other studies have observed positive correlations [38] or even no correlations [54]. In this study, it was observed that the $\mathrm{Hg}$ fluxes were negatively correlated with the relative humidity. Generally speaking, increases in solar radiation and air temperature tend to lead to decreases in relative humidity, which may be the main cause of the negative correlation. Second, increased relative humidity can potentially combine vapor and mercury. Meanwhile, vapor can occupy air gaps in the soil and block the release of soil gases [55].

In this study, soil moisture was found to be negatively correlated with the fluxes. This had differed from several previous reported results, in which positive correlations between the soil moisture and the Hg fluxes were identified under controlled laboratory settings, as well as during some field investigations $[55,56]$. Precipitation has also been believed to influence $\mathrm{Hg}$ emissions in several ways, such as the desorption of $\mathrm{Hg}^{0}$ in the soil matrix by water molecules; reduction in $\mathrm{Hg}^{2+}$ by dissolved organic matter, $\mathrm{O}_{3}, \mathrm{Fe}^{2+}$, and/or biotic mechanisms, and then transported to the surface with water vapor [55]. However, it was determined that one of the most important reasons for the differing results was that there were no rainy days during this study's measurement processes, and the soil moisture varied diurnally followed by high solar radiation levels.

\subsubsection{GEM Concentrations in the Air and Soil}

Air is an important $\mathrm{Hg}$ "pool" and can influence the Hg transmission to other "pools." Recent studies have shown the ambient-air $\mathrm{Hg}^{0}$ concentration levels determine the direction of $\mathrm{Hg}$ movement [5]. If the $\mathrm{Hg}^{0}$ concentrations are at relatively low levels (3.26 to $10.8 \mathrm{ng} \cdot \mathrm{m}^{-3}$ ), the fluxes will be positively related to the $\mathrm{Hg}^{0}$ concentrations [57]. However, the studies conducted in high-level $\mathrm{Hg}$ regions have indicated that high air $\mathrm{Hg}^{0}$ concentrations (122 to $284 \mathrm{ng} \cdot \mathrm{m}^{-3}$ ) have negative effects on released fluxes and may even result in air $\mathrm{Hg}^{0}$ sediment in the soil, although the soil will contain more $\mathrm{Hg}$ (150 to $260 \mathrm{ng} \cdot \mathrm{g}^{-1}$ ) than local background level [57]. In this study, the air $\mathrm{Hg}^{0}$ concentrations were observed to be positively correlated with the $\mathrm{Hg}$ fluxes in all the obtained measurements $(p<0.05)$. The possible reason was that the air $\mathrm{Hg}^{0}$ concentrations were driven by the emission fluxes. It was speculated that this had also led to the observed air $\mathrm{Hg}^{0}$ diel and seasonal variable patterns.

Along with the air pools, the pool effects of the soil are also considered to be very important. Numerous studies have reported that there is a significantly positive correlation between the soil Hg concentrations and the surface-Hg fluxes [5]. In this study, not only no significant correlations could be found between the soil $\mathrm{Hg}$ concentrations and the fluxes but also there were unobvious seasonal varieties in the soil $\mathrm{Hg}$ concentrations, with the maximum values reached in July. A common explanation is that the temperature and rainfall levels in July had promoted organic matter accumulation, which led to the strong sorption of $\mathrm{Hg}$ to functional groups on the soil organic matter [58,59]. 


\section{Conclusions}

This study represents the first-time measurements of the exchange fluxes of GEM over soil-air interfaces under the conditions of different vegetation types. The study area was located in the Songnen Grasslands region of northeastern China. The results indicated that the GEM fluxes over the soil-air surfaces ranged from $-18.0 \mathrm{ng} \cdot \mathrm{m}^{-2} \cdot \mathrm{h}^{-1}$ to $47.3 \mathrm{ng} \cdot \mathrm{m}^{-2} \cdot \mathrm{h}^{-1}$, with a mean value of $4.3 \mathrm{ng} \cdot \mathrm{m}^{-2} \cdot \mathrm{h}^{-1}$ to $9.0 \mathrm{ng} \cdot \mathrm{m}^{-2} \cdot \mathrm{h}^{-1}$ at the plant coverage and removal treatments in the Songnen Grasslands, during the growing season in 2018. Therefore, it was assumed that natural meadow steppe regions are significant local atmospheric emission sources. In this study, the fluxes exhibited diurnal and seasonal patterns, in which the emissions were usually observed during the daytime hours, the depositions were observed during the nighttime hours, and the peak flux values were reached during the summer (July). This study also found that vegetation played an important role in the GEM exchange processes in that it inhibited the emission fluxes through absorbing atmospheric $\mathrm{Hg}$. Moreover, the fluxes were found to have significant correlations with solar radiation, air/soil temperature, and air/soil humidity levels. However, solar radiation was determined to be the most important factor affecting the $\mathrm{Hg}$ fluxes in the Songnen Grasslands steppe region. Overall, the data obtained in this study provided a basis for estimating the $\mathrm{Hg}$ budget from similar terrestrial surfaces and also supported the prior findings regarding the relationships between environmental factors and $\mathrm{Hg}$ fluxes.

Author Contributions: Conceptualization, G.Z. and Z.W.; methodology, X.Z., X.L. (Xu Li) and G.Z.; software, X.Z.; validation, L.W., G.Z. and Z.W.; formal analysis, X.L. (Xiangyun Li), Z.L., Z.Y., R.H. and Y.Z.; resources, G.Z.; data curation, G.Z; writing—original draft preparation, G.Z. and X.Z.; writing-review and editing, G.Z. and Z.W.; visualization, L.W.; supervision, D.W. and Z.T.; project administration, Z.W.; funding acquisition, Z.W. All authors have read and agreed to the published version of the manuscript.

Funding: This study was funded by the Chinese National Natural Science Foundation of China (Grant No. 31230012, 31770520); Key Social Development Project of Jilin Science and Technology Department of China (Grant No. 20190303068SF).

Institutional Review Board Statement: Not applicable.

Informed Consent Statement: Not applicable.

Data Availability Statement: The data presented in this study are available on request from the corresponding author.

Acknowledgments: We are grateful to the Key Laboratory of Vegetation ecology of the Ministry of Education for its help and support.

Conflicts of Interest: The authors declare no conflict of interest.

\section{References}

1. Driscoll, C.T.; Mason, R.P.; Chan, H.M. Mercury as a global pollutant: Sources, pathways, and effects. Environ. Sci. Technol. 2013, 47, 4967-4983. [CrossRef] [PubMed]

2. Kim, M.K.; Zoh, K.D. Fate and transport of mercury in environmental media and human exposure. J. Prev. Med. Public Health 2012, 45, 335-343. [CrossRef] [PubMed]

3. Harding, G.; Dalziel, J.; Vass, P. Bioaccumulation of methylmercury within the marine food web of the outer Bay of Fundy, Gulf of Maine. PLoS ONE 2018, 13, e09772. [CrossRef] [PubMed]

4. Kang, H.H.; Liu, X.L.; Guo, J.M. Increased mercury pollution revealed by tree rings from the China's Tianshan Mountains. Life Sci. Bull. 2018, 63, 1328-1331. [CrossRef]

5. Eckley, C.S.; Blanchard, P.; Mclennan, D.; Mintz, R.; Sekela, M. Soil-Air mercury flux near a large industrial emission source before and after closure. Environ. Sci. Technol. 2015, 49, 9750-9757. [CrossRef] [PubMed]

6. Agnan, Y.; Le Dantec, T.; Moore, C.W.; Edwards, G.C.; Obrist, D. New constraints on terrestrial surface atmosphere fluxes of gaseous elemental mercury using a global database. Environ. Sci. Technol. 2016, 50, 507-524. [CrossRef]

7. Grigal, D.F. Inputs and outputs of mercury from terrestrial watersheds: A review. Environ. Rev. 2002, 10, 1-39. [CrossRef]

8. Cizdziel, J.V.; Jiang, Y.; Nallamothu, D. Air/surface exchange of gaseous elemental mercury at different landscapes in Mississippi, USA. Atmosphere 2019, 10, 538. [CrossRef]

9. Krabbenhoft, D.P.; Sunderland, E.M. Global change and mercury. Science 2013, 341, 1457-1458. [CrossRef] 
10. Carpi, A.; Fostier, A.H.; Orta, O.R. Gaseous mercury emissions from soil following forest loss and land use changes: Field experiment on the United States and Brazil. Atmos. Environ. 2014, 96, 423-429. [CrossRef]

11. Jiskra, M.; Wiederhold, J.G.; Skyllberg, U. Mercury deposition and re-emission pathways in boreal forest soils investigated with Hg isotope signatures. Environ. Sci. Technol. 2015, 49, 7188-7196. [CrossRef]

12. Tom, S.; Gordon, M.; David, R. Gaseous mercury flux from salt marshes is mediated by solar radiation and temperature. Atmos. Environ. 2017, 153, 117-125.

13. Sommar, J.; Zhu, W.; Shang, L.H. Seasonal variations in metallic mercury (Hg0) vapor exchange over biannual wheat-corn rotation cropland in the North China Plain. Biogeosciences 2016, 13, 2029-2049. [CrossRef]

14. Bengtsson, J.; Bullock, J.M.; Egoh, B. Grasslands-More important for ecosystem services than you might think. Ecosphere 2019, 10, e02582. [CrossRef]

15. Howard, D.; Edwards, G.C. Mercury fluxes over an Australian alpine grassland and observation of nocturnal atmospheric mercury depletion events. Atmos. Chem. Phys. 2018, 18, 129-142. [CrossRef]

16. Kikuchi, T.; Ikemoto, H.; Takahashi, K. Parameterizing soil emission and atmospheric oxidation reduction in a model of the global biogeochemical cycle of mercury. Environ. Sci. Technol. 2013, 47, 12266-12274. [CrossRef] [PubMed]

17. Simone, F.D.; Gencarelli, C.N.; Hedgecock, I.M. Global atmospheric cycle of mercury: A model study on the impact of oxidation mechanisms. Environ. Sci. Pollut. Res. 2014, 21, 4110-4123. [CrossRef] [PubMed]

18. Ericksen, J.A.; Gustin, M.S.; Schorran, D.E. Accumulation of atmospheric mercury in forest foliage. Atmos. Environ. 2003, 37, 1613-1622. [CrossRef]

19. Stamenkovic, J.; Gustin, M.S. Nonstomatal versus stomatal uptake of atmospheric mercury. Environ. Sci. Technol. 2009, 43, 1367-1372. [CrossRef]

20. Gustin, M.S.; Lindberg, S.E.; Weisberg, P.J. An update on the natural sources and sinks of atmospheric mercury. Appl. Geochem. 2008, 23, 482-493. [CrossRef]

21. Pirrone, N.; Cinnirella, S.; Feng, X.B. Global mercury emissions to the atmosphere from anthropogenic and natural sources. Atmos. Chem. Phys. 2010, 10, 5951-5964. [CrossRef]

22. Bergamaschi, B.A.; Krabbenhoft, D.P.; Aiken, G.R. Tidally driven export of dissolved organic carbon, total mercury, and methyl-mercury from a mangrove-dominated estuary. Environ. Sci. Technol. 2012, 46, 1371-1378. [CrossRef]

23. Ci, Z.J.; Peng, F.; Xue, X. Air-surface exchange of gaseous mercury over permafrost soil: An investigation at a high-altitude (4700 m a.s.l.) and remote site in the central Qinghai-Tibet Plateau. Atmos. Chem. Phys. 2016, 16, 14741-14754. [CrossRef]

24. Mu, C.C.; Schuster, P.F.; Abbott, B.W. Permafrost degradation enhances the risk of mercury release on Qinghai-Tibetan Plateau. Sci. Total Environ. 2020, 708, 135. [CrossRef]

25. Converse, A.D.; Riscassi, A.L.; Scanlon, T.M. Seasonal variability in gaseous mercury fluxes measured in a high-elevation meadow. Atmos. Environ. 2010, 44, 2176-2185. [CrossRef]

26. Sun, S.W.; Ma, M.; He, X.B. Vegetation mediated mercury Flux and atmospheric mercury in the alpine permafrost region of the central Tibetan Plateau. Environ. Sci. Technol. 2020, 54, 6043-6052. [CrossRef] [PubMed]

27. Lee, R.; Yu, F.F.; Price, K.P. Evaluating vegetation phenological patterns in Inner Mongolia using NDVI timeseries analysis. Int. J. Remote Sens. 2002, 23, 2505-2512. [CrossRef]

28. Wang, L.; Liu, H.; Ketzer, B. Effect of grazing intensity on evapotranspiration in the semiarid grasslands of Inner Mongolia. J. Arid Environ. 2012, 83, 15-24. [CrossRef]

29. Zhu, W.; Lin, C.J.; Sommar, J. Emission characteristics and air-surface exchange of gaseous mercury at the largest active landfill in Asia. Atmos. Environ. 2013, 79, 188-197. [CrossRef]

30. Lin, C.J.; Zhu, W.; Li, X. Novel dynamic flux chamber for measuring air-surface exchange of Hg0 from soils. Environ. Sci. Technol. 2012, 46, 8910-8920. [CrossRef]

31. Zhu, W.; Sommar, J.; Li, Z. Highly elevated emission of mercury vapor due to the spontaneous combustion of refuse in a landfill. Atmos. Environ. 2013, 79, 540-545. [CrossRef]

32. Eckley, C.S.; Gustin, M.S.; Lin, C.J. The influence of dynamic chamber design and operating parameters on calculated surface-to-air mercury fluxes. Atmos. Environ. 2010, 44, 194-203. [CrossRef]

33. Streets, D.G.; Horowitz, H.M.; Jacob, D.J. Total mercury released to the environment by human activities. Environ. Sci. Technol. 2017, 51, 5969-5977. [CrossRef]

34. Xin, M.; Gustin, M.; Johnson, D. Laboratory investigation of the potential for re-emission of atmospherically derived Hg from soils. Environ. Sci. Technol. 2007, 41, 4946-4951. [CrossRef] [PubMed]

35. Kinsey, J.S.; Anscombe, F.R.; Lindberg, S.E.; Southworth, G.R. Characterization of the fugitive mercury emissions at a chlor-alkali plant: Overall study design. Atmos. Environ. 2003, 38, 633-641. [CrossRef]

36. Fu, X.; Feng, X.; Wang, S. Mercury flux rate of two types of grasslands in Guiyang. Res. Environ. Sci. 2007, $20,33-37$.

37. Qin, J. Mercury in soil, vegetable and human hair in a typical mining area in China: Implication for human exposure. J. Environ. Sci. 2018, 68, 73-82.

38. Carpi, A.; Frei, A.; Cocris, D. Analytical artifacts produced by a polycarbonate chamber compared to a Teflon chamber for measuring surface mercury fluxes. Chemosphere 2007, 388, 361-365. [CrossRef] 
39. Zhang, H.; Lindberg, S.E.; Barnett, M.O. Dynamic flux chamber measurement of gaseous mercury emission fluxes over soils. Part 1: Simulation of gaseous mercury emissions from soils using a two-resistance exchange interface model. Atmos. Environ. 2002, 36, 835-846. [CrossRef]

40. Artaxo, P.; Calixto, D.; Campos, R.; Fernandes, E.T. Large-scale mercury and trace element measurements in the Amazon basin. Atmos. Environ. 2000, 34, 4085-4096. [CrossRef]

41. Wang, D.; He, L.; Shi, X. Release flux of mercury from different environmental surfaces in Chongqing, China. Chemosphere 2006, 64, 1845-1854. [CrossRef]

42. Carpi, A.; Lindberg, S.E. Sunlight-mediated emission of elemental mercury from soil amended with municipal sewage sludge. Environ. Sci. Technol. 1997, 31, 2085-2091. [CrossRef]

43. Li, Z.G.; Feng, X.; Li, P.; Liang, L. Emissions of air-borne mercury from five municipal solid waste landfill in Guiyang and Wuhan, China. Atmos. Environ. 2010, 10, 2072-2079. [CrossRef]

44. Lindberg, S.E.; Hanson, P.J.; Meyers, T.P. Air/surface exchange of mercury vapor over forests e the need for a reassessment of continental biogenic emissions. Atmos. Environ. 1998, 32, 895-908. [CrossRef]

45. Fay, L.; Gustin, M. Assessing the influence of different atmospheric and soil mercury concentrations on foliar mercury concentrations in a controlled environment. Water Air Soil Pollut. 2007, 181, 373-384. [CrossRef]

46. Mazur, M.E.E.; Mitchell, C.P.J.; Eckley, C.S. Gaseous mercury fluxes from forest soils in response to forest harvesting intensity: A field manipulation experiment. Sci. Total Environ. 2014, 496, 678-687. [CrossRef]

47. Gustin, M.S.; Stamenkovic, J. Effect of watering and soil moisture on mercury emission fromsoils. Biogeochemistry 2005, 76, 215-232. [CrossRef]

48. Wang, L.; Manuel, D.B.; Wang, D.L. Diversifying livestock promotes multidiversity and multifunctionality in managed grasslands. Proc. Natl. Acad. Sci. USA 2019, 116, 6187-6192. [CrossRef] [PubMed]

49. Miller, M.B.; Gustin, M.S. Testing and modeling the influence of reclamation and control methods for reducing nonpoint mercury emissions associated with industrial open pit gold mines. J. Air Waste Manag. Assoc. 2013, 63, 681-693. [CrossRef]

50. Rutter, A.P.; Schauer, J.J.; Shafer, M.M. Climate sensitivity of gaseous elemental mercury dry deposition to plants: Impact of temperature, light intensity, and plant species. Environ. Sci. Technol. 2011, 45, 569-575. [CrossRef] [PubMed]

51. Choi, H.D.; Holsen, T.M. Gaseous mercury fluxes from the forest floor of Adirondacks. Environ. Pollut. 2009, 157, 592-600. [CrossRef]

52. Lindberg, S.E.; Jackson, D.; Huckabee, J. Atmospheric emission and plant uptake of mercury from agricultural soils near the Almaden mercury mine. J. Environ. Qual. 1979, 8, 572-578. [CrossRef]

53. Gustin, M.S.; Ericksen, J.A.; Schorran, D.E. Application of controlled mesocosms for understanding mercury air/soil-plant exchange. Environ. Sci. Technol. 2004, 38, 6044-6050. [CrossRef]

54. Gills, A.A.; Miller, D.R. Some local environmental effects on mercury emission and absorption at a soil surface. Sci. Total Environ. 2000, 260, 191-200. [CrossRef]

55. Briggs, C.; Gustin, M.S. Building upon the conceptual model for soil mercury flux: Evidence of a link between moisture evaporation and Hg evasion. Water Air Soil Pollut. 2013, 224, 1774. [CrossRef]

56. Park, S.Y.; Hoslen, T.M.; Kim, P.R. Laboratory investigation of factors affecting mercury emissions from soils. Environ. Earth Sci. 2014, 72, 2711-2721. [CrossRef]

57. Miller, M.B.; Gustin, M.S. Gas-exchange chamber analysis of elemental mercury deposition/emission to alluvium, ore, and mine tailings. Chemosphere 2015, 113, 209-216. [CrossRef]

58. Obrist, D.; Johnson, D.W.; Lindberg, S.E. Mercury concentrations and pools in four Sierra Nevada forest sites, and relationships to organic carbon and nitrogen. Biogeosciences 2009, 6, 765-777. [CrossRef]

59. Yu, X.; Driscoll, C.T.; Warby, R.A.F. Soil mercury and its response to atmospheric mercury deposition across the northern United States. Ecol. Appl. 2014, 24, 812-822. [CrossRef] 